\title{
Chickpea (Cicer arietinum) Growth and Productivity Changes through Acquisition of Limiting Nutrients (Nitrogen-N and Phosphorus-P) by Rhizobium and Microphos
}

\author{
Santosh Kumari* \\ Division of Plant Physiology, Indian Agricultural Research Institute, New Delhi, India \\ *Corresponding author
}

\begin{abstract}
A B S T R A C T
This study clearly showed the benefit of $\mathrm{P}$ availability in combination with Rhizobium on leaf area, leghaemoglobin content, nitrate reductase activities of leaves and nodules, fresh

Keywords

Cicer, Microphos,

Nodulation,

Phosphorus,

Rhizobium.

\section{Article Info}

Accepted:

21 September 2017

Available Online:

10 October 2017 and dry weight of nodules and fresh weights of stem + leaves at vegetative and flowering stages. Yield components, pod number and seed number were significantly increased by $\mathrm{P}$ availability by fertilizer alone and in combination with Rhizobium or through Rhizobium +Microphos. Seed test weight and number of seeds clearly demonstrated the benefit of rhizobium and microphos (P-solubilizing bacteria) inoculation in organic farming of legumes and cost saving of crop production in terms of inorganic fertilizer production. The study demonstrated that the inoculants are suitable for mass production and commercialization for improving crop yield. Microphos work slowly for P liberation from organic and inorganic pools, improved nitrogen fixation efficiency, help in development of extensive root system bearing maximum number of nodules by sustained availability of $\mathrm{P}$ from the soil conditions used for growing control plants. Improved crop yields components and nodulation response of plants exhibit that phosphate solubilizing bacteria can be successfully used in combination with $\mathrm{N} 2$ fixing symbiont to ensure the most efficient use of least mobile and limited supplies of rock phosphate fertilizer.
\end{abstract}

\section{Introduction}

The chickpea (Cicer arietinum) is protein rich grain legume used for human as well as animal consumption. Chickpeas are grown in post rainy winter season and largely in arid and semi-arid environment. Plant symbioses help in acquisition of limiting nutrients and regulate plant productivity under nutrient poor ecosystems. Microbes can have direct effect through root associated pathogenic relationship (Sprent and Parsons, 2000) or indirect effect of free living microbes via altering rates of nutrient supply and partitioning of resources. Nitrogen (N), phosphorus $(\mathrm{P})$ and potassium $(\mathrm{K})$ together are key elements to control plant growth and productivity. Nitrogen fixing bacteria regulate plant productivity by fixing atmospheric nitrogen (N).P-solubilizing bacteria constituting $40 \%$ of cultivable population of soil bacteria (Kucey, 1983) solubilize various forms of precipitated $\mathrm{P}$ from weathering soils via exudation of organic acids (Landeweert et al., 2001) and increase availability to the plants. Microphos can enhance P uptake and 
fulfill high-P requirement for productivity of legumes. P-solubilizing bacteria improve soil health, cause no pollution, protect plants against soil borne pathogens and involve low cost technology in their production and save cost of chemical fertilizer production. Understanding the influence of rhizobium and microphos on $\mathrm{N}$ and $\mathrm{P}$ acquisition and their interaction in increasing plant productivity is crucial to develop integrated strategies to promote crop growth and sustainable agriculture. Therefore, the study was undertaken to analyse Chickpea (Cicer arietinum) growth and productivity changes through acquisition of limiting nutrients (nitrogen-N and phosphorus-P) by Rhizobium and Microphos.

\section{Materials and Methods}

Chickpea or Bengal gram (variety BG383) plants were raised in cement pots containing field soil and manure. Seeds were treated with rhizobium and microphos cultures before sowing. Phosphate fertilizer $\mathrm{P}_{2} \mathrm{O}_{5}$ was applied at the rate of $6.25 \mathrm{~g} /$ pot i.e. $0.08 \mathrm{~g} / \mathrm{kg}$ of air dry soil for phosphate alone and in combination with Rhizobium. Three replicates were sampled for each observation at three stages of growth; vegetative, flowering and maturity. Leaf area was recorded with leaf area meter (Li-3100). The rate of photosynthesis was measured by InfraRed Gas Analyzer (ADC-225MK3). Chlorophyll extraction was done in $80 \%$ ethanol and estimated following Arnon (1949). Nitrate reductase activity was essayed in vivo following Klepper et al., (1971). Leghaemoglobin extraction and estimation was done following Drabkin and Austin (1935) from bigger pink nodules from all treatments. Plant components were separated into leaves, nodules, root, stem, pods and seeds for fresh weight and kept at $80^{\circ} \mathrm{C}$ for dry weight analysis. Sun dried seeds were weighed for seed test weight.
Nitrate reductase in vivo was assayed following the method of Klepper et al., (1971).

Statistical analysis for ANOVA was done using MStat software.

\section{Results and Discussion}

Phosphate $\left(\mathrm{P}_{2} \mathrm{O}_{5}\right)$, Rhizobium, Rhizobium + $\mathrm{P}_{2} \mathrm{O}_{5}$, and Rhizobium + Microphos increased leaf area/plant over control and maximum value were obtained at flowering stage. Maximum Leaf area, fresh weight and dry weight of nodule were significantly increased by $\mathrm{P}_{2} \mathrm{O}_{5}$ application in Rhizobium inoculated plants followed by Rhizobium alone and in combination with phosphate solubilizing bacteria at flowering stage. Acquisitions of phosphate at vegetative stage by microphos treatment help in biomass formation through formation and growth of nodules (highest number of nodules) and thereby higher nitrogen fixation. Nitrate reductase activity in nodules was significantly high with phosphate supply followed by Rhizobium $+\mathrm{P}_{2} \mathrm{O}_{5}$ and Rhizobium + Microphos at flowering stage. Nitrate reductase activity recorded was the highest in Cicer leaves and nodules at vegetative stage under Rhizobium inoculation followed by Rhizobium + Microphos. Leghaemoglobin content were associated with increased size of the nodules with phosphorus supply $\left(\mathrm{P}_{2} \mathrm{O}_{5}>\right.$ Rhizobium + Microphos > Rhizobium $+\mathrm{P}_{2} \mathrm{O}_{5}>$ Rhizobium) those values were further increased at flowering stage in $\mathrm{P}_{2} \mathrm{O}_{5}$ and Rhizobium $+\mathrm{P}_{2} \mathrm{O}_{5}$ treatments. Lower value for Leghaemoglobin indicated the faster mobilization of nitrogen from senescing bacteroids to the developing pods and seed. Nitrate reductase activity in Cicer leaves and nodules followed the trends in Leghaemoglobin and chlorophyll content at vegetative stage of growth. Nitrate reductase activity in leaves and nodules was remarkably increased by phosphorus supply at flowering stage. Microphos with Rhizobium treatment 
balanced nitrate reductase activity of nodules from vegetative to flowering stage. Highest biomass and nodule number on extensive root system (mass +length) were observed in Rhizobium + Microphos treatment Total biomass and 100 seed weight showed association with supply of $\mathrm{P}_{2} \mathrm{O}_{5}$ fertilizer. Phosphorus supply increased the fresh weight of leaves and stem in all combinations over control and Rhizobium alone. While nodule were the biggest in size but number were reduced with inorganic $\mathrm{P}_{2} \mathrm{O}_{5}$ application. Nitrogen fixation builds up early canopy/ leaf area with higher activity of nitrate reductase. These differences were displayed in leaves even at flowering stage in Cicer and $\mathrm{P}$ availability increased the efficiency of Rhizobium treatment in building up leaf area. Total fresh and dry mass of nodules were higher with Rhizobium treatments but Leghaemoglobin content were lower than phosphate alone or in combination with nitrogen fixing symbiont. The nodule sizes were the biggest on tap/main root of Cicer under only $\mathrm{P}_{2} \mathrm{O}_{5}$ followed by control $>$ Rhizobium $>$ Rhizobium $+\mathrm{P} 2 \mathrm{O} 5>$ Rhizo bium + Microphos treatments. The number of nodules/plant increased with resource mobilization from shoot to root with availability of fixed nitrogen and phosphorus $(13>29>70>74>105)$ in control $>\mathrm{P}_{2} \mathrm{O}_{5}>$ Rhizobium $>$ Rhizobium $+\mathrm{P}_{2} \mathrm{O}_{5}>$ Rhizobium + Microphos, respectively. The size of nodules formed on deeper roots decreased with the increase in number especially in Rhizobium + Microphos treatment. Significant (P-value $=0.03)$ positive correlation $(\mathrm{r}=0.93))$ was observed between photosynthesis and fresh weight of nodules. P utilization from the upper $0-30 \mathrm{~cm}$ soil depth result in formation of the bigger nodules in control compared to those of Rhizobium $>$ Rhizobium+P2O5 $>$ Rhizobium + Microphos. In the absence of Rhizobium inoculation, nitrogen fixation became limiting for the synthesis of chlorophyll, and enzymatic proteins of photosynthesis those were reflected in lower values of photosynthesis, leaf area, fresh and dry weight of nodules in control plants. Phosphorus supply mobilized newly fixed carbon dioxide to the nodules and increased the fresh and dry weight of total nodules per plant. Rhizobium + Microphos increased leaf area, fresh and dry weight of nodule, shoot biomass, seed number and 100seed weight (Table 1).

The host, chickpea plant, provided carbon and nitrogen to the developing and growing nodules by reallocation and remobilization of resources from its parts. In young plants newly formed photosynthetic products are used for expenditure of energy for nodule production before any benefit of $\mathrm{N}_{2}$ fixation. The photo assimilates transported via phloem support the growth of nodules and bacteria; provide energy for nitrogen fixation in endophyte; ammonia assimilation (excreted from bacteroids) in host cytosol, and synthesis of ureide or amide for export from the nodule.

The ureides/amides contribute to the soluble nitrogen pool of the host and their catabolic products are assimilated in macromolecules DNA, RNA, proteins and specific amino acids of secondary metabolites. Chickpea export both amides i.e. asparagine (ASN) and ureides i.e. allantoin (ALN) and allantoic acid (ALC).The energy consuming reactions of ammonia assimilation are directly coupled with energy generating reactions in the light while in the dark, specific reductants and ATP is generated from consumption of photosynthates. Therefore, nitrate reductase activity (inducible in light) in nodules and leaves was found to be limited by nitrogen fixation in control and by $\mathrm{P}$ availability in Rhizobium treated plants. A complementary role of nitrate reductase to those of nitrogenase had been suggested (Serrano and Chamber, 1990) and correlated with nitrogen metabolism of whole plant (Table 2). 
Table.1 Effect of $\mathrm{P}_{2} \mathrm{O}_{5}$, Rhizobium, Rhizoium $+\mathrm{P}_{2} \mathrm{O}_{5}$ and Rhizobium + Microphos on leaf area, fresh weight of nodules, dry weight of nodules, biomass, seed number and seed test weight in Chickpea

\begin{tabular}{|c|c|c|c|c|c|}
\hline \multicolumn{6}{|c|}{ Vegetative } \\
\hline & $\begin{array}{l}\text { Leaf } \\
\text { Area } \\
\left(\mathrm{cm}^{2}\right)\end{array}$ & $\begin{array}{l}\text { Fresh Wt. } \\
\text { of Nodules } \\
(\mathrm{g})\end{array}$ & $\begin{array}{l}\text { Dry Wt. } \\
\text { of } \\
\text { Nodules } \\
(\mathrm{g})\end{array}$ & $\begin{array}{l}\text { Fresh weight } \\
\text { of Stem } \\
\text { +Leaves }(\mathrm{g})\end{array}$ & 100-Seed Wt. (g) \\
\hline Control & 170 & 2.04 & 0.70 & 22.70 & 16.20 \\
\hline Rhizobium & 351 & 2.45 & 1.00 & 44.35 & 17.27 \\
\hline Rhizobium $+\mathbf{P}_{2} \mathrm{O}_{5}$ & 256 & 3.70 & 2.06 & 42.68 & 20.84 \\
\hline $\mathbf{P}_{2} \mathbf{O}_{5}$ & 264 & 2.32 & 1.00 & 44.22 & 19.54 \\
\hline Rhizobium+Microphos & 290 & 3.71 & 1.97 & 46.75 & 17.54 \\
\hline C.D. $5 \%$ & 1.71 & 0.08 & 0.03 & 0.39 & 0.12 \\
\hline \multicolumn{6}{|r|}{ Seed Number plant ${ }^{-1}$} \\
\hline Control & 600 & 2.54 & 1.90 & 58.50 & 19 \\
\hline Rhizobium & 2078 & 4.48 & 3.21 & 67.00 & 23 \\
\hline Rhizobium $+\mathbf{P}_{2} \mathrm{O}_{5}$ & 3265 & 7.73 & 4.97 & 83.00 & 33 \\
\hline $\mathbf{P}_{2} \mathbf{O}_{5}$ & 1199 & 4.24 & 2.33 & 92.00 & 35 \\
\hline Rhizobium+Microphos & 2026 & 3.62 & 2.50 & 75.67 & 34 \\
\hline C.D. $5 \%$ & 617 & 2.42 & 0.02 & 0.56 & \\
\hline
\end{tabular}

Table.2 Effect of $\mathrm{P}_{2} \mathrm{O}_{5}$, Rhizobium, Rhizoium $+\mathrm{P}_{2} \mathrm{O}_{5}$ and Rhizobium + Microphos on Photosynthesis, chlorophyll content, Leghaemoglobin content, nitrate reductase activity of leaves and nodules in chickpea

\begin{tabular}{|c|c|c|c|c|c|}
\hline \multicolumn{6}{|c|}{ Vegetative } \\
\hline & $\begin{array}{l}\text { Photosynthesis } \\
\left(\mu \text { moles } \mathrm{CO}_{2} \mathrm{~cm}^{-}\right. \\
{ }_{2} \mathrm{~S}^{-1}\end{array}$ & $\begin{array}{l}\text { Chlorophyll } \\
\text { (mg g }{ }^{-1} \text { f.wt.) }\end{array}$ & $\begin{array}{l}\text { Leghaemoglobin } \\
\text { (mg g }{ }^{-1} \text { f.wt.) }\end{array}$ & $\begin{array}{c}\text { NR activity of } \\
\text { Leaves (nmolesg } \\
{ }^{1} \text { f.wt.) }\end{array}$ & $\begin{array}{l}\text { NR activity of } \\
\text { Nodules } \\
\text { (nmolesg }{ }^{-1} \\
\text { f.wt.) }\end{array}$ \\
\hline Control & 14.07 & 2.09 & 6.36 & 140 & 325 \\
\hline Rhizobium & 17.01 & 2.70 & 6.78 & 410 & 380 \\
\hline Rhizobium $+\mathbf{P}_{2} \mathbf{O}_{5}$ & 22.05 & 2.74 & 6.92 & 305 & 315 \\
\hline $\mathbf{P}_{2} \mathbf{O}_{5}$ & 19.11 & 2.79 & 11.50 & 280 & 370 \\
\hline Rhizobium+Microphos & 15.12 & 2.52 & 10.31 & 350 & 505 \\
\hline C.D. $5 \%$ & 3.01 & 0.02 & 1.18 & 3.23 & 5.19 \\
\hline \multicolumn{6}{|c|}{ Flowering } \\
\hline Control & 14.14 & 2.35 & 2.07 & 100 & 300 \\
\hline Rhizobium & 17.43 & 2.37 & 1.70 & 175 & 325 \\
\hline Rhizobium $+\mathbf{P}_{2} \mathrm{O}_{5}$ & 22.50 & 2.34 & 1.65 & 150 & 550 \\
\hline $\mathbf{P}_{2} \mathbf{O}_{5}$ & 19.60 & 2.35 & 1.47 & 750 & 700 \\
\hline Rhizobium+Microphos & 15.75 & 2.43 & 1.77 & 225 & 500 \\
\hline C.D. $5 \%$ & 2.24 & 0.03 & 0.09 & 5.55 & 3.12 \\
\hline
\end{tabular}


The turnover of insoluble nitrogen pool i.e. macromolecules feeds the soluble $\mathrm{N}$ pool for recycling (catabolism, reassimilation and resynthesis of nitrogenous compounds).Organic nitrogen for newly expanding leaves is delivered from xylem whereas $\mathrm{N}$ for seed growth to a great extent arrives through phloem. Recently fixed $\mathrm{N}_{2}$ is used to meet the $\mathrm{N}$ requirement of the nodules and approximately $50 \%$ of $\mathrm{N}$ requirement of nodule and root growth is met from the soluble pool of shoot through phloem.

Therefore, nitrogen deficiency may limit the leaf area generation, photosynthetic surface/ machinery (chloroplast, chlorophylls and enzymes), photo assimilates, root growth, nodule growth, pod number, seed number and biomass production. Phosphorus deficiencies further accentuate the biomass reduction through limited supply of UTP, ATP, NADPH and nucleotides for the synthesis of macromolecules like starch, protein, RNA and DNA. However, extensive root system was produced under nitrogen fixing bacteria and phosphate solubilizing bacteria, therefore, availability of both the nutrients increased acquisition efficiency of the root system and utilization efficiency of the shoot.

Tiny white nodules were developed under deeper soils due to the sustained availability of $\mathrm{P}$ by increasing surface area of roots and increasing diffusion of nutrients. While increased nodule growth by $\mathrm{P}$ utilization in upper soil $0-30 \mathrm{~cm}$ depth in pots consequently compensated by reduced leaf areas under control $\left(\mathrm{No} \mathrm{P}_{2} \mathrm{O}_{5}\right)$ and $\mathrm{P}_{2} \mathrm{O}_{5}$ treatment.

Higher rates of photosynthesis accompanied with higher leaf area may be able to support higher nitrogen fixation reflected from higher leghaemoglobin content of nodules and nitrate reductase activities in leaves and nodules under Rhizobium, Rhizobium $+\mathrm{P}_{2} \mathrm{O}_{5}$ and Rhizobium + Microphos treatments.
Remarkably high nitrate reductase activity under $\mathrm{P}_{2} \mathrm{O}_{5}$ treatment at flowering stage indicated the importance of $\mathrm{P}$ in reductants supply for ammonia assimilation. Our study clearly showed the benefit of $\mathrm{P}$ availability in combination with Rhizobium on leaf area, fresh and dry weight of nodules and dry weights of stem + leaves at vegetative and flowering stages. Yield components, pod number, seed number and 100-seed weight were significantly increased by $\mathrm{P}$ fertilizer alone and in combination with Rhizobium or through Rhizobium + Microphos. Our results exhibited the importance of $\mathrm{P}$ nutrition in grain weight and grain yield (Dixit et al., 1993; Gupta et al., 1998).Phosphorus requirement for cell division, nodule development, root development and nitrogen fixation has been argued earlier (Marschner, 1995).

Our study suggest the increased efficiency of nitrogen fixation by slow release of $\mathrm{P}$ from soil by microphos in comparison of $\mathrm{P}_{2} \mathrm{O}_{5}$ application for increased formation of reproductive sinks i.e. buds, pods and seeds by changing hormonal balance especially cytokinin in favour of cell division activities. Previous study revealed that nitrogenase activity declined in smaller nodules of chickpea with increasing soil depth (Khanna et al., 1987). High concentration of nitrogenous compounds, flowing into the surrounding of root nodules, with the phloem sap from the lower leaves could inhibit both the nodule growth and nitrogenase activity (Parson et al., 1993). However, the reduction in size of nodules under salt stress was attributed to the lower activity of the meristematic zone and reduced number of symbiotic bacteria (Babber et al., 2000).

In conclusion the growth and productivity of Chickpea was influenced by the availability of nutrients in the rhizosphere controlled by plant characteristics such as leaf area, 
photosynthesis, nodulation efficiency, leghaemoglobin content, nitrate reductase activities in leaves and roots, root growth and interaction of microbes with plant root system. Microphos enhanced nitrogen and Phosphorus acquisition and use efficiency of chickpea in terms of grain yield production.

\section{Acknowledgement}

Chickpea seed material inoculated with Rhizobium and Microphos provided by Division of Microbiology, IARI at Delhi, India is thankfully acknowledged.

\section{References}

Arnon, D. I., 1949. Copper Enzymes in Isolated Chloroplasts. Polyphenol Oxidases in Beta Vulgaris. PlantPhysiol, 24: 1-15.

Babber, S., Sheokand S. and Malik, S. 2000. Nodule Structure and Functioning in Chickpea (Cicer arietinum) as Affected by Salt Stress. Biol. Plant., 43(2): 269-273.

Chopra, R. K., Khanna, S. and Kumari, S. 1987. Rhizobia Population, Nodulation and Nitrogen Fixation at Various Soil Depths in Cicer arietinum Cultivars. Proceedings of DEA Symposium on Plant- Microbe Interactions. University of Maharani's College, Jaipur (November11-13, 1987) Organized by Department of Atomic Energy, Govt. of India

Dixit, J. P., Dubey, O. P. and Soni, N. P. 1993.Effect of Sowing Date and Irrigation on Yield and Nutrient Uptake by Chickpea (Cicer arietinum L.) cultivars under Tawa Command area. Indian J. Agron., 38: 227231.

Drabkin, D. L., and Austin, J. H. 1935.
Spectrophotometric Studies: ii. Preparations from Washed Blood Cells; Nitric Oxide, Hemoglobin and Sulfhemoglobin. J. Biol. Chem., 112: 51-65.

Gupta, A. K., Kaur, V. and Kaur, N. 1998. Appearance of Different Phosphatase Forms and Phosphorus Partitioning in Nodules of Chickpea (Cicer arietinum L.) during Development. Acta Physiol. Plant.,20: 369-374.

Klepper, L., Flesher, D. and Hageman, R. H. 1971. Generation of Reduced Nicotinamide Adenine Dinucleotide for Nitrate Reductase in Green Leaves. Plant Physiol., 48: 580590. doi:10.1104/pp.48.5.

Kucey, R.M.N., 1983. Phosphate Solubilizing Bacteria and Fungi in Various Cultivated and Virgin Alberta Soils. Can. J. Soil Sci., 63: 671-678.

Landeweert, R., Hoffland, E., Finlay, R.D., Kuyper, T.W. and van Breemen, N. 2001. Linking Plants to Rocks: Ectomycorrhizal Fungi Mobilize Nutrients from Minerals. Trends Ecol. Evol., 16: 248-254.

Marschner, H., 1995. Mineral Nutrition of Higher Plants. Academic Press Inc. London LTD, 645.

Parsons, R., Stanforth, A., Raven, J. A. and Sprent, J. I. 1993. Nodule Growth and Activity may be regulated by a Feedback Mechanism Involving Phloem Nitrogen. Plant Cell Environ, 16: 125-136.

Serrano, A., and Chamber, M. 1990. Nitrate Reduction in Bradyrhizobium sp (Lupinus) Strain and its Effects on their Symbiosis with Lupinus luteus. J. Plant Physiol., 136: 240-246.

Sprent, J.I., and Parsons, R. 2000. Nitrogen Fixation in Legume and Non-legume Trees. Field Crops Res., 65: 183-196.

\section{How to cite this article:}

Santosh Kumari. 2017. Chickpea (Cicer arietinum) Growth and Productivity Changes through Acquisition of Limiting Nutrients (Nitrogen-N and Phosphorus-P) by Rhizobium and Microphos. Int.J.Curr.Microbiol.App.Sci. 6(10): 2381-2386.

doi: https://doi.org/10.20546/ijcmas.2017.610.281 